\title{
Regulasi Penulisan Buku Ajar bagi Dosen di Perguruan Tinggi
}

\author{
Mira Mirnawati \\ Jurusan Perencanaan Wilayah Universitas Bina Taruna Gorontalo \\ Miramirnawati4279@gmail.com \\ Abdul Rahmat \\ Jurusan Pendidikan Luar Sekolah Universitas Negeri Gorontalo \\ abdulrahmat@ung.ac.id
}

Received: 22 August 2021; Revised: 02 October 2021; Accepted: 28 December 2021

DOI: http://dx.doi.org/10.37905/aksara.8.1.751-758.2022

\begin{abstract}
Abstrak
Jumlah terbitan buku ajar yang kurang dari $10 \%$ dari total dosen aktif berdasarkan data PDDikti menjadi pemicu ditulisnya penelitian ini. Tujuan penelitian ini untuk menemukan dan menganalisis regulasi dan dokumen lainnya terkait penulisan buku ajar bagi dosen. Harapannya, dengan adanya analisis ini dapat memotivasi dosen untuk semangat menulis buku ajar. Jenis penelitian ini adalah penelitian kepustakaan. Data primer berupa regulasi dan dokumen yang diterbitkan oleh pemerintah dan data sekunder berupa artikel dan data statistik yang diperoleh dari laman-laman pemerintah. Teknik analisis data menggunakan metode content analysis. Hasil dan pembahasan menunjukkan bahwa terdapat regulasi pemerintah terkait buku ajar didukung oleh buku pedoman dan buku panduannya, tetapi tidak ada yang secara spesifik menjelaskan cara buku ajar ditulis. Buku pedoman dan buku panduan baru menjelaskan teknik penyusunan kurikulum. Inilah yang mungkin menjadi peneybab dosen tidak termotivasi untuk menulis buku ajar.
\end{abstract}

Kata Kunci: regulasi buku ajar, dokumen buku ajar, buku ajar, penulisan buku ajar, perguruan tinggi

\section{PENDAHULUAN}

Lingkungan akademik seperti di kampus dituntut untuk kental dengan nuansa literasi. Oleh karena itu, tidak heran ketika dosen, mahasiswa, dan tenaga kependidikan bersama-sama berupaya menciptakan iklim akademik yang literat. Salah satu bentuk upaya menciptakan iklim akademik bernuansa literasi adalah masyarakatnya menulis buku dan membaca buku.

Kehadiran buku menjadi salah satu bentuk nyata mendukung terciptanya iklim akademik di kampus. Alangkah indahnya ketika setiap sudut kampus dipertontonkan perilaku membaca baik yang dilakukan oleh dosen, mahasiswa atau tenaga kependidikan. Selain itu, tidak kalah kerennya jika didapati dosen atau mahasiswa di sudut-sudut taman sedang berdiskusi tentang buku.

Pertanyaannya kemudian, siapakah yang paling tepat untuk menulis buku di lingkungan kampus? Setiap orang dapat menulis, tetapi tidak semua orang mampu menulis apalagi buku. Buku bukan tulisan pendek yang dapat ditulis dalam hitungan jam. Menulis buku membutuhkan proses. 
Dosen atau mahasiswa memiliki potensi untuk menulis buku. Bahkan dosen diwajibkan menulis buku sesuai dengan pedoman operasional penilaian angka kredit (PO PAK) dan pedoman operasional beban kerja dosen (PO BKD). Salah satu buku yang wajib ditulis oleh dosen adalah buku ajar (Dirjen Sumber Daya Iptek dan Dikti, 2019; Kepdirjendikti, 2021).

Buku ajar berbeda dengan buku lainnya seperti buku monograf atau buku referens. Buku ajar dikenal juga dengan buku teks yang merupakan terjemahan dari bahasa Inggris textbook. Buku teks juga bersinonim dengan buku pelajaran, tetapi buku ajar berbeda dengan buku pelajaran. Walaupun tata cara penulisannya hampir sama, tetapi buku pelajaran berbeda pembaca sasarannya dengan buku ajar. Buku pelajaran ditujukan untuk siswa dan buku ajar untuk mahasiswa.

Buku ajar wajib ditulis oleh dosen setiap tahun sebanyak satu buku berdasarkan PO PAK maupun PO BKD. Kewajiban ini belum dapat dipenuhi oleh semua dosen. Berdasarkan informasi yang diperoleh di laman isbn.perpusnas.go.id, tahun 2021 telah diterbitkan buku ajar beri-ISBN sebanyak 1.674 judul. Trennya meningkat jika dilihat dari penerbitannya setiap tahun walaupun peningkatannya tidak terlalu signifikan. Tahun 2019, buku ajar ber-ISBN sebanyak 1.241 dan tahun berikutnya 2020 terbit sebanyak 1.517. Selisihnya 276 judul. Namun, dibanding dengan tahun 2016 yang hanya dapat menerbitkan 445 judul (Perpustakaan Nasional Republik Indonesia, 2022).

Jumlah buku ajar yang diterbitkan di Indonesia masih jauh dibandingkan dengan jumlah dosen yang berada di Indonesia. Tercatat, jumlah dosen laki-laki 166.979 orang dan 129.061 orang (Pangkalan Data Pendidikan Tinggi, 2022). Total dosen laki-laki dan perempuan adalah 296.040. Angka ini menginformasikan bahwa pencapaian dengan terbitnya 1.674 judul buku ajar, masih menyisakan 295.363 dosen yang belum menulis buku ajar. Dengan catatan apabila dihitung satu dosen satu buku ajar, karena kenyataannya boleh jadi 1 dosen menulis lebih dari satu judul.

Kondisi ini memperlihatkan bahwa penulisan buku ajar yang ditulis oleh dosen masih dalam jumlah yang sedikit, bahkan masih jauh dari $10 \%$ total dosen. Oleh karena itu, peneliti tertarik untuk menelusuri tentang regulasi dan dokumen pendukung yang dapat memotivasi dosen sebagai penulis buku ajar. Jika setelah diteliti ternyata ada regulasi dan dokumen pendukung, maka perlu ditelusuri lebih lanjut tentang faktor penyebab dari penulis (dosen) tidak menulis buku ajar.

Penelitian tentang analisis regulasi dan dokumen tentang buku ajar di Indonesia belum ditemukan. Begitupun dengan penelitian tentang minat menulis buku ajar belum ditemukan berdasarkan pencarian di google scholar. Namun, penelitian tentang pengembangan buku ajar banyak ditemukan di google scholar. Hal ini menunjukkan geliat penulisan buku ajar masih dalam tahap upaya peningkatan melalui penelitian pengembangan. Boleh jadi adanya ketidakpercayaaan diri di lingkungan penulis buku ajar dalam hal ini dosen untuk menulis buku ajar dengan benar. Oleh karena itu penting ditelusuri melalui penelitian ini terkait dengan regulasi dan dokumen pendukung tentang buku ajar di Indonesia.

\section{METODE PENELITIAN}

Penelitian ini bertujuan untuk menelusuri dan menganalisis regulasi atau dokumen yang diterbitkan oleh pemerintah terkait dengan buku ajar atau penulisan buku ajar di Indonesia. Oleh karena itu, penelitian ini menggunakan pendekatan kualitatif dengan menerapkan metode penelitian kepustakaan (library research). Penelitian berbasis 
kepustakaan merupakan bentuk penelitian yang menggunakan literatur sebagai objek kajian.

Data yang digunakan dalam penelitian ini berupa data primer dan sekunder. Data primer berupa dokumen-dokumen yang diterbitkan oleh pemerintah baik berupa undangundang, permen, pertuaran pemerintah, buku pedoman, buku panduan, dan dokumen sejenis yang terkait dengan buku ajar. Data sekunder juga digunakan sebagai pelengkap penelitian baik berupa artikel ilmiah, data statistik dari laman-laman pemerintah, dan data sekunder lainnya yang mendukung proses analisis untuk mencapai tujuan penelitian.

Setelah data ditemukan, kemudian dianalisis untuk menjawab permasalahan sebagai tujuan penelitian. Teknik analisis yang digunakan adalah teknik content analysis. Dalam teknik ini diperlukan data untuk menjawab setiap tahap penelitian, kemudian dilakukan analisis data (Sawarjuwono \& Kadir, 2003).

\section{HASIL DAN PEMBAHASAN}

\section{Hasil Penelitian}

Buku ajar dalam bahasa Inggris dikenal dengan textbook yang diterjemahkan ke dalam bahasa Indonesia menjadi buku teks. Buku teks di Indonesia termasuk dalam jenis buku pendidikan seperti yang dijelaskan dalam Undang-Undang Nomor 3 Tahun 2017 tentang Sistem Perbukuan.

Undang-Undang Nomor 3 Tahun 2017 tentang Sistem Perbukuan adalah salah satu regulasi yang mengatur tentang buku di Indonesia. Regulasi lainnya beserta dokumen pendukungnya yang berhasil dikumpulkan terkait dengan buku ajar adalah sebagai berikut.

1. Undang-Undang Republik Indonesia Nomor 20 Tahun 2003 tentang Sistem Pendidikan Nasional dan Permendiknas tahun 2008 tentang Buku

Regulasi ini tidak menjelaskan tentang buku ajar ataupun buku secara umum.

2. Undang-Undang Republik Indonesia Nomor 12 Tahun 2012 Tanggal 10 Agustus 2012 tentang Pendidikan Tinggi

Regulasi ini tidak menjelaskan tentang buku ajar ataupun buku secara umum walaupun menjelaakan tentang pendidikan tinggi.

3. Undang-Undang Republik Indonesia Nomor 3 Tahun 2017 tentang Sistem Perbukuan dan turunannya.

Regulasi ini tidak menjelaskan buku ajar. Namun, dijelaskan tentang bentuk, jenis, dan isi buku. Bentuk buku terdiri atas buku cetak dan buku elektronik. Jenis buku terdiri atas buku pendidikan dan buku umum. Buku berisi ilmu pengetahuan, informasi, dan hiburan.

Buku pendidikan terdiri atas buku teks dan buku nonteks. Buku teks terdiri atas buku teks utama dan buku teks pendamping. Buku teks utama merupakan buku pelajaran yang wajib digunakan dalam pembelajaran berdasarkan kurikulum yang berlaku dan disediakan oleh pemerintah pusat tanpa dipungut biaya. Buku teks pendamping merupakan buku palajaran yang disusun oleh masyarakat berdasarkan kurikulum yang berlaku dan telah mendapatkan pengesahan dari pemerintah pusat (Peraturan Pelaksanaan Undang-Undang Nomor 3 Tahun 2017 Tentang Sistem Perbukuan, 2019; Undang-Undang Republik Indonesia Tentang Sistem Perbukuan No. 3, 2017).

Buku ajar tidak disebutkan apalagi dijelaskan, tetapi pada pasal 6 ayat 9 dijelaskan mengenai buku pendidikan diatur dengan peraturan pemerintah. Peraturan 
pemerintah yang dimaksud adalah Peraturan Pemerintah Nomor 75 Tahun 2019 tentang Pelaksanaan Undang-Undang RI Nomor 3 Tahun 2017. Selain itu, pada pasal 52 ayat 1 dijelaskan bahwa buku pendidikan yang diterbitkan oleh perguruan tinggi harus memenuhi syarat isi .

\section{Pembahasan}

Buku ajar tidak dijelaskan dalam undang-undang bahkan pada undang-undang tentang sistem perbukuan. Buku yang dijelaskan pada undang-undang yang mendekati dengan jenis buku ajar adalah buku pendidikan jenis buku teks.

Buku ajar termasuk kategori buku pendidikan karena ditulis dan digunakan di lingkungan pendidikan. Oleh karena itu, buku ajar dapat mengikuti aturan umum untuk buku pendidikan jenis buku teks seperti yang diatur oleh undang-undang.

Berdasarkan Undang-Undang Nomor 3 Tahun 2017, tiga hal yang perlu diperhatikan untuk menulis buku pendidikan yang akan dikuti oleh aturan menulis buku ajar, yaitu sebagai berikut.

1. Buku ajar harus ditulis berdasarkan kurikulum yang berlaku. Hal ini sesuai dengan Undang-Undang Republik Indonesia Nomor 3 Tahun 2017 dan Peraturan pemerintah Nomor 75 tahun 2019 yang menyatakan bahwa buku teks merupakan buku yang disusun untuk pembelajaran berdasarkan standar nasional pendidikan dan kurikulum yang berlaku.

Kurikulum di perguruan tinggi diatur dalam Permendikbud Nomor 3 Tahun 2020 tentang Standar Nasional Perguruan Tinggi. Penjelasan terkait kurikulum dalam regulasi ini yaitu sebagai berikut (Permendikbud, 2020).

1) Kurikulum adalah seperangkat rencana dan pengaturan mengenai tujuan, isi, dan bahan pelajaran serta cara yang digunakan sebagai pedoman penyelenggaraan untuk mencapai tujuan pendidikan tinggi.

2) Program studi adalah kesatuan kegiatan pendidikan dan pembelajaran yang memiliki kurikulum dan metode pembelajaran tertentu dalam satu jenis pendidikan akademik, pendidikan profesi, dan/atau pendidikan vokasi.

3) Standar nasional pendidikan tinggi wajib dijadikan dasar penyelenggaraan pembelajaran berdasarkan kurikulum pada program studi.

4) Standar nasional pendidikan menjadi acuan dalam menyusun, menyelenggarakan, dan mengevaluasi kurikulum.

5) Unit pengelola program studi sebagai pelaksana standar pengelolaan wajib melakukan penyusunan kurikulum dan rencana pembelajaran dalam setiap mata kuliah.

Rencana pembelajaran dalam setiap mata kuliah biasa disebut dengan RPS yang merupakan singkatan dari rencana pembelajaran semester. RPS menjadi dasar disusunnya buku ajar. Hal ini disebabkan karena buku ajar ditulis berdasarkan capaian pembelajaran lulusan (CPL). CPL menggambarkan kebutuhan materi yang harus diperoleh mahasiswa.

Materi yang dibutuhkan maahasiswa untuk mencapai tujuan pembelajaran dapat dilihat dari indikator capaiannya. Indikator diperoleh dari subcapaian pembelajaran mata kuliah. Subcapaian pembelajaran mata kuliah diperoleh dari capaian pembelajaran mata kuliah (CPMK) dan CPMK diperoleh dari CPL. 
Menyusun CPL dapat dilihat pada buku Panduan Penyusunan Capaian Pembelajaran Lulusan Program Studi yang diterbitkan oleh Direktorat Pembelajaran dan Kemahasiswaaan Direktorat Jendral Pendidikan Tinggi Kementrian dan Kebudayaan Tahun 2014. CPL program studi merupakan rumusan tujuan pembelajaran yang harus dicapai dan wajib dimiliki oleh semua lulusannya. Program studi wajib memiliki rumusan CPL yang dapat dipertanggungjawabkan baik isi, kelengkapan deskripsi sesuai dengan ketentuan dalam SN Dikti, serta kesetaraan level kualifikasinya dengan KKNI (Belmawa, 2014).

Dasar hukum CP dinyatakan dalam Peraturan Presiden Nomor 8 Tahun 2012 tentang Kerangka Kualifikasi Nasional Indonesia (KKNI). KKNI pada sistem pendidikan tinggi dinyatakan dalam Undang-Undang Republik Indonesia Nomor 12 Tahun 2012 tentang Pendidikan Tinggi (Peraturan Presiden Republik Indonesia, 2012; Undang-Undang Republik Indonesia Nomor 12 Tahun 2012 Tentang Pendidikan Tinggi, 2012).

Setelah CPL dirumuskan, kemudian disusun kurikulum dengan mengikuti Buku Panduan Penyusunan Kurikulum Perguruan Tinggi MBKM yang terbit tahun 2020 menggantikan panduan kurikulum sebelumnya yang terbit tahun 2016. Penjelasan dalam buku tersebut diantaranya memaparkan tentang tahapan menyusun kurikulum di perguruan tinggi yang terdiri atas dua tahapan, yaitu tahapan perancangan dokumen kurikulum dan tahapan perancangan pembelajaran.

Tahapan perancangan pembelajaran dimulai dengan merumuskan CPMK.CPMK adalah CPL yang dibebankan pada mata kuliah. CPMK diturunkan lagi menjadi beberapa sub-CPMK. Sub-CPMK diturunkan lagi menjadi beberapa indikator.

Setelah menyusun CPMK, sub-CPMK, dan indikator, kemudian dilanjutkan menyusun rencana pembelajaran semester (RPS). Dalam menyusun RPS juga harus disiapkan diantaranya materi pembelajaran yang direncanakan. Materi pembelajaran ini dapat disajikan dalam bentuk buku ajar (panduan MBKM).

2. Buku ajar (buku teks) harus memenuhi syarat isi sesuai dengan Undang-Undang Republik Indonesia Nomor 3 Tahun 2017 Bab II Pasal 48 yaitu buku diterbitkan setelah memenuhi persyaratan sebagai berikut.

a. Telah memenuhi syarat isi sebagaimana dimaksud Pasal 42 ayat (5).

Syarat isi pada Pasal 42 ayat (2) terdiri atas lima hal yaitu sebagai berikut.

1) Tidak bertentangan dengan nilai-nilai Pancasila.

2) Tidak diskriminatif berdasarkan suku, agama, ras, dan/atau.

3) Tidak mengandung unsur pronografi.

4) Tidak mengandung unsur kekerasan.

5) Tidak mengandung ujaran kebencian.

b. Mencantumkan angka standar buku internasional sebagaimana dalam Pasal 30 yang dijelaskan pada huruf $\mathrm{f}$ yaitu yang dimaksud dengan angka standar buku internasional yang unik untuk terbitan buku. Maksud dari ayat ini adalah international standard book number (ISBN).

3. Buku ajar ditulis sesuai dengan standar, kaidah, dan kode etik pemerolehan dan penerbitan naskah yang tertera pada Undang-Undang RI nomor 3 Bab III Bagian Kesatu Pasal 7. Ruang lingkup standar yang dimaksud meliputi standar mutu buku dan standar proses pemerolehan naskah dan penerbitan buku. 
Standar mutu buku pendidikan terdiri atas standar materi, standar penyajian, standar desain, dan standar grafika. Standar materi merupakan standar pemenuhan isi buku dan standar kelayakan isi buku. Standar kelayakan buku teks mencakup aspek:

a. Kebenaran dari segi keilmuan;

b. Kesesuaian dengan standar nasional pendidikan dan kurikulum yang berlaku;

c. Kesesuaian dengan perkembangan ilmu pengetahuan dan teknologi;

d. Kesesuaian dengan konteks dan lingkungan; dan

e. Kesatupaduan antarbagian isi buku.

Standar penyajian buku mencakup aspek berikut ini.

a. Kelayakan penyampaian isi buku sesuai dengan tingkat perkembangan peserta didik

b. Kelayakan penggunaan bahasa yang tepat dan komunikatif sesuai dengan tingkat penguasaan bahasa peserta didik.

Satndar desain dan standar grafika juga harus diperhatikan. Standar desain merupakan standar penggunaan ilustrasi, desain halaman isis, dan desain kover buku sesuai dengan perkembangan peserta didik. Berbeda dengan standar grafika merupakan standar kualitas hasil cetak dan hasil tampilan elektronik yang ramah pengguna, aman, dan nyaman .

Berdasarkan analisis pada beberapa dokumen pemerintah terkait dengan buku ajar, terdapat aturan yang dapat dijadikan sebagai rujukan untuk menulis buku ajar. Namun, secara teknis dan detail belum ada panduan penulisan buku ajar sehingga lebih memudahkan dosen sebagai penulis buku ajar menyusun buku ajar sesuai dengan harapan.

Upaya pemerintah untuk memotivasi dosen menulis buku ajar dapat dilihat pada Pedoman operasional penilaian angka kredit (PO PAK) 2019 dan suplemennya serta pedoman opersaional beban kerja dosen (PO BKD). Dalam PO PAK dijelaskan bahwa dosen harus mengembangkan bahan pengajaran dalam bentuk buku ajar minimal satu buku per tahun. Begitupun sama halnya dengan PO BKD yang menjelaskan bahwa dosen baik perorangan maupun berkelompok wajib menulis buku ajar atau buku teks yang diterbitkan oleh perguruan tinggi maupun lembaga penerbit lainnya (Dirjen Sumber Daya Iptek dan Dikti, 2019; Kepdirjendikti, 2021).

\section{SIMPULAN}

Rendahnya jumlah terbitan buku ajar dapat disebabkan tidak adanya buku panduan yang menguraikan tentang cara menulis buku ajar dengan benar. Adanya satu persepsi tentang penyusunan atau penulisan buku ajar akan lebih memudahkan dosen menulisnya. Regulasi dan apresiasi dari pemerintah sudah lengkap bahkan detail, tetapi belum disertakan buku panduan yang merupakan tahapan akhir secara teknis.

\section{Rekomendasi}

Penelitian ini menghasilkan dua rekomendasi sebagai berikut.

1. Penelitian ini belum menyentuh persepsi penulis buku ajar dan penggunanya, sehingga sangat dimungkinkan untuk dilakukan penelitian lanjutan untuk memperoleh informasi tentang penyebab rendahnya terbitan buku ajar. 
2. Penting untuk diterbitkan buku panduan penulisan buku ajar agar memudahkan dosen menulisnya. Melahirkan persepsi tentang konsep yang sama dalam diri dosen untuk menulis buku ajar dapat memudahkan mereka menuliskannya sesuai dengan harapan pemerintah untuk menghadirkan buku ajar yang berkualitas.

\section{DAFTAR PUSTAKA}

Belmawa, T. K. (2014). Panduan Penyusunan Capaian Pembelajaran Lulusan Program Studi.

Dirjen Sumber Daya Iptek dan Dikti. (2019). Pedoman Operasional Penilaian Angka Kredit Kenaikan Jabatan Akademik/Pangkat Dosen (p. 68). http://lldikti12.ristekdikti.go.id/wp-content/uploads/2019/03/PO-PAK-

2019_MULAI-BERLAKU-APRIL-2019.pdf

Kepdirjendikti. (2021). Pedoman Operasional Beban Kerja Dosen.

Pangkalan Data Pendidikan Tinggi. (2022). Grafik Jumlah Dosen Aktif Berdasarkan Jenis Kelamin. https://pddikti.kemdikbud.go.id/dosen

Peraturan Pelaksanaan Undang-Undang Nomor 3 Tahun 2017 tentang Sistem Perbukuan, 1 (2019). https://peraturan.bpk.go.id/Home/Details/122497/pp-no-75-tahun-2019

Peraturan Presiden Republik Indonesia. (2012). Kerangka Kualifikasi Nasional Indonesia Nomor 8 Tahun 2012 (Issue 8).

Permendikbud. (2020). Peraturan Menteri Pendidikan Dan Kebudayaan Republik Indonesia Nomor 3 Tahun 2020 Tentang Standar Nasional Pendidikan Tinggi. Menteri Pendidikan Dan Kebudayaan RI, 1-76.

Perpustakaan Nasional Republik Indonesia. (2022). Hasil Pencarian Buku Ajar berdasarkan Judul. https://isbn.perpusnas.go.id/Account/SearchBuku?searchTxt=buku+ajar\&searchCa $\mathrm{t}=$ Judul

Sawarjuwono, T., \& Kadir, A. P. (2003). Intelectual Capital: Perlakuan, Pengukuran, dan Pelaporan (Sebuah Library Research). Jurnal Akuntansi Dan Keuangan, 5(1), 3557.

Undang-Undang Republik Indonesia Nomor 12 Tahun 2012 tentang Pendidikan Tinggi, Pub. L. No. Nomor 12, Republik Indonesia (2012).

Undang-undang Republik Indonesia Tentang Sistem Perbukuan No. 3, (2017). 
AKSARA: Jurnal Ilmu Pendidikan Nonformal

P-ISSN 2407-8018 E-ISSN 2721-7310 DOI prefix $\underline{10.37905}$

Volume 08, (1), January 2022

http://ejurnal.pps.ung.ac.id/index.php/Aksara

758 AKSARA: Jurnal Ilmu Pendidikan Nonformal 